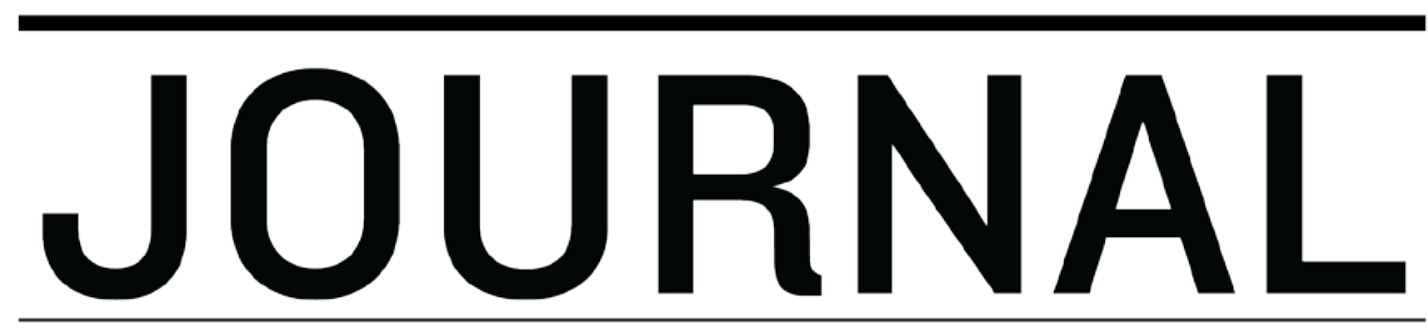

OF LIVING ARCHITECTURE

A GREEN INFRASTRUCTURE FOUNDATION PUBLICATION

Volume 4 Number 1 Pages 1-13

2017

\title{
Kelp extract (Ascophyllumnodosum) can improve health and drought tolerance of green roof plants
}

\author{
Stephanie Appleby-Jones ${ }^{1}$, Jeremy Lundholm, ${ }^{1 *}$ Amy Heim ${ }^{1}$ \\ ${ }^{1}$ Department of Biology, Saint Mary's University
}

\begin{abstract}
The soil additive Ascophyllumnodosum (Norwegian kelp) can increase drought tolerance of plants, and promote seed germination, yet there has been no published research testing this amendment on green roofs. Liquid A. nodosum extract in two volumes and a slow release fertilizer were tested in a pot culture experiment for annuals, perennial cultivars, and three native species. Kelp extract did not improve the germination percentage of any of these species. In drought conditions both on a green roof and in the greenhouse, kelp treatments increased plant biomass relative to controls for some species only; plant health and longevity weregenerally improved when kelp was applied as an amendment. Soil water content was higher in kelp treated pots compared to fertilizer treated pots, and higher than controls in kelp treated pots for some species. Application of this local renewable resource to green roof plants could help to improve plant and substrate health while improving drought tolerance of plants on green roofs.
\end{abstract}

KEY WORDS: soil amendment, fertilizer, Norwegian kelp, soil moisture, seaweed extract

Please Cite as: Appleby-Jones, S., J. Lundholm, and A, Heim, 2017. Kelp extract (Ascophyllumnodosum) can improve health and drought tolerance of green roof plants.Journal of Living Architecture.4(1): 1-13 


\section{INTRODUCTION}

Green roofs provide many benefits for building occupants and the greater urban environment (Dvorak and Volder 2010).Green roofs aid in the mitigation of rising urban temperatures (Saadatian et al. 2013), attenuate urban noise (Rowe, B., 2011), extend the life of building membranes (McDonough and Braungart 2002), reduce stormwater runoff (CzemielBerndtsson 2010), provide habitat for flora and fauna (Oberndorfer et al. 2007), and reduce human stress by providing green space for spiritual renewal, peace, and quietness in what can be a noisy, concrete-dominated urban environment (Yuen and Hien 2005).

Visually pleasing green roof design can include selecting a variety of plant species that exhibit structural differences, an extended flowering period, and a mixture of coloured foliage so they are appreciated by the public (Fernadez-Canero et al. 2013). Besides public acceptance, diverse green roofs can offer improved ecosystem services (Lundholm et al. 2010).Monterusso et al. (2005) found that native plant diversity on a Michigan green roof declined over a three-year period with some species completely dying out while Sedum sp. survived over the same period.The researchers recommended that without irrigation, green roof plants must be drought resistant, cover the substrate quickly, and be able to self-seed or propagate by roots. Plants can be directly seeded onto a green roof substrate and many existing plant species on a roof will produce seed (Kircher 2004). Successful growth from a viable seed development into a healthy plant is important in terms of species survival in a green roof plant community.Köhler and Poll (2010) evaluated modern green roofs in Germany and found 70 different vascular species growing on them. The research found that floral quality was greatly reduced with water deficiency. Green roofs can be designed for species diversity, but research into plant survival and health is warranted. The research reported here explored a diversity of plant species using three eastern North American natives, four non-native green roof cultivars, and three annual cultivars (chosen for their ability to self-seed).

Slow release fertilizer is commonly applied at planting time to provide the new plants with the essential nutrients that are needed to grow and thrive on a roof (Emilsson, et al. 2007).Adding amendments to soil can help to improve the growing conditions for plant communities (Ohsowski et al. 2012).In Nova Scotia, extensive beds of Ascophyllumnodosum (Norwegian kelp) grow in intertidal shores (Ugarte and Sharpe 2012) making them an easily assessable resource for this region.Seaweeds have been proven to contain biochemical compounds that promote growth of both roots and shoots of terrestrial plants (Thorsen et al 2010; Rayorath et al. 2008). Betaines and betaine-like compounds found in A. nodosum extracts help alleviate osmotic and drought stress. When added as an amendment, kelp extract and seaweed meal can increase organic matter, improve aeration and aggregate stability of soil (Crouch and Staden 1993; Haslam and Hopkins 1996). The increased pore volume and soil stability can have a positive effect in water relations of plants that are exposed to drought (Spann and Little 2011). Seed germination can also be significantly improved (Thorsen et al. 2010).Gibberellins and cytokinins are known plant growth regulators present in fresh seaweed and seaweed extracts (Crouch and van Staden 1993; Khan et al. 2009; Thorsen et al. 2010; Papenfus, et al. 2013). These hormones may help seeds to overcome germination 
inhibitors and increase germination (Thorsen et al. 2010). There has been no information found in the literature where $A$. nodosum has been tested in green roof research.

Objectives of the study were to evaluate and compare seed germination and early growth of plants using various soil amendment treatments. The performance of plants during a short term, six-day drought and a long term, two-month drought was evaluated.We wanted to find which species and treatments offered superior growth and performance during the trial.Extreme environmental conditions exist on green roofs, including strong solar radiation and high winds that can quickly dry out the substrate. During the trial, soil moisture and plant survival were analyzed to evaluate if the amendments could aid in plant health and survival during drought on a green roof.

\section{MATERIALS AND METHODS}

Ten plant species were chosen for a greenhouse experimentthat took place at Saint Mary's University campus in Halifax, Nova Scotia.Three perennial, native species which grow on the coastal barrens of Nova Scotia were selected.An industry partner, Vitaroofs (1087 Meyerside Drive, Unit 8 Mississauga, Ontario L5T 1M5 Canada), supplied four perennial species. Three of the species are not native to Nova Scotia and one, Deschampsiacaespitosa, is native. However, this seed was not from the ecoregion and therefore evaluated with the non-native plants.Three annual, non-native cultivars were selected and purchased from Halifax Seed (Halifax, Nova Scotia, Canada).Twenty seeds were planted in each pot (plastic, terracotta colour, 5.5” Jumbo Square Pot, Myers Industries Lawn \& Garden Group, Middlefield, OH, USA) by sprinkling seeds on top of Sopraflor X green roof soil (Soprema Inc., Drummondville, QC, Canada). Soprema X consists of crushed brick, blond peat, perlite, sand, and vegetable compost with a total porosity between $50-60 \%$ and a bulk density between $1100-1200 \mathrm{~kg} / \mathrm{m}^{3}$. Three samples of twenty seeds from each species were weighed and a mean was established. Seed was lightly rubbed into the soil to aid seed to soil contact and to provide a light soil cover.Soil depth was $10 \mathrm{~cm}$ and volume of soil was $1200 \mathrm{ml}$ per pot. Plant species in the study were, Eschscholziacalifornica 'Prize Mixture', Lobulariamaritima'Snowcloth Alyssum', Portulacagrandiflora'Double Mixed Colours', Anthoxanthumodoratum, D.caespitosa,Luzulanivea, Poasupina,

Festucarubra,Luzulamultiflora, and Saginaprocumbens were planted between May 1-3, 2013.For the germination portion of the experiment, the plants were grown in the greenhouse located on the lower green roof which is approximately $5 \mathrm{~m}$ above ground.Greenhouse temperatures ranged from $25 / 18^{\circ} \mathrm{C}$ (day/night) with the photoperiod: $16 / 8$ hours (day/night) and light intensity $250 \mathrm{umol} / \mathrm{m}^{2}$, plus natural light.

Three hundred and twenty pots were used in the germination portion of this experiment, using eight replicates per plant species per amendment treatment.The "K+" treatment was $3.5 \mathrm{ml}$ of liquid kelp (Batch \#13582, Acadian Seaplants, Dartmouth, Nova Scotia, Canada) per litre of water, the "k-" treatment was $1.5 \mathrm{ml}$ of liquid kelp per litre of water, the "F" treatment was $2.5 \mathrm{ml}$ of $10 \mathrm{~N}: 10 \mathrm{P}: 10 \mathrm{~K}$ Scott's Miracle-Gro® Shake 'n Feed Slow Release Plant Food per pot, and the "C" treatment was a control in which no amendments were added. Upon planting, pots and seeds were immediately watered according to their treatment $(\mathrm{K}+$ and $\mathrm{k}$ - were watered with appropriate amount of liquid kelp and water 
while $\mathrm{F}$ and $\mathrm{C}$ treatments were watered with water and no liquid kelp) using $500 \mathrm{ml}$ of liquid per pot.Plants were watered weekly.After two weeks, it was decided that the water be reduced to $250 \mathrm{ml}$ of water until the last application on August 1, 2013. Pots were placed in a complete randomized block design, approximately two centimetres apart, in rows of ten, directly on the greenhouse bench.

\section{Greenhouse germination trial}

Percent germination was evaluated for all species and treatments. Once the germination counts were concluded, a random selection of three pots per species and treatment (120 pots) were removed from the experiment. Above ground biomass was harvested from these pots and dried in a $40^{\circ} \mathrm{C}$ oven for approximately twenty-four to thirty-six hours before weighing.

\section{Green roof trial}

On June 14, 2013 the remaining 200 pots were moved out onto the upper Atrium green roof at Saint Mary's University (approximately 25 metres above ground height). The pots were kept in the same randomized order as in the germination trial and seedlings were thinned out to three plants per pot or less.Watering and kelp treatments continued and plant health was evaluated using health scores (Table 1).

Soil moisture was also monitored and after a six-day drought on July 17, 2013, percent volumetric water content (VWC) was measured using a soil moisture/temperature probe, ProCheck GS3 soil moisture sensor (Decagon Devices Inc., Pullman, WA, USA) to compare differences in soil moisture content between the ten species and four treatments.

Table 1.Health scores and plant health description for ten species of green roof plants exposed to drought on Saint Mary’s green roof and in the greenhouse.Adapted from Butler \&Orians (2011), Monterusso et al. (2005), and Nagase \&Dunnett (2010)

\begin{tabular}{c|c}
\hline Health score & Physical description \\
\hline 3 & Healthy, green leaves with very few brown tips \\
2 & Less than 50\% yellow or brown leaves \\
1 & $\begin{array}{c}\text { Greater than } 50 \% \text { yellow or brown leaves or stems, wilting, 50\% of leaves absent or folded } \\
(\text { Luzula), or shrivelled (Portulaca), grasses with slight moisture in crown }\end{array}$ \\
0 & Dead, could have green leaves but are dried, no moisture in crown of grasses \\
\hline
\end{tabular}

\section{Greenhouse dry-down trial}

On July 31, 2013 all 200 pots were moved back into the greenhouse. On August 1, 2013 the final kelp treatments and watering were applied to all pots.

VWC and plant health scores were conducted three times per week from August 1, 2013 until September 30, 2013.As each plant died, the date of death was recorded and the biomass was harvested.The pots with soil were left in situ for the remainder of the experiment.This was so the soil moisture of the remaining plants would not be affected by an empty space (edge). 


\section{RESULTS AND DISCUSSION}

\section{Germination}

In the first eight days of germination, significant differences were found on the third, fourth, and fifth day of data collection for L.multiflora between the k- treatment (higher germination) and the $\mathrm{F}$ treatment (lower germination).No other significant differences were observed. Theearliest germination for L.maritima, A.odoratum, and S.procumbenswas recorded in the k- treatment and the earliest germination for P.grandifloraoccurred in the $\mathrm{F}$ treatment.Since early germination in the $\mathrm{K}+$ treatment was notobserved for any species,the dose of liquid kelp used could have created a negative effect on germinating seeds.

No significant difference was observed between treatments for percent germination. For L.maritima, A.odoratum, F.rubra, and S.procumbensthe highest percent germination was observed in the k- treatment.For E.californica, P.grandiflora, and D. caespitosathe highest percent germination was observed in the F treatment.ForL.nivea, P.supina, and L.multiflorathe highest percent germination was observed in the $\mathrm{C}$ treatment. For L.maritima, A.odoratum, L.nivea, and L.multiflora the lowest percent germination was observed in the $\mathrm{F}$ treatment. ForP.supina, and S.procumbensthe lowest percent germination was observed in the $\mathrm{K}+$ treatment. For P.grandiflorathe lowest percent germination was observed in the ktreatment. For F.rubrathelowest percent germination was observed in the $\mathrm{C}$ treatment. For E.californicaand $D$. caespitosathelowest percent germination was a tie between the $\mathrm{K}+$ and $\mathrm{k}$ treatments (Figure 1).

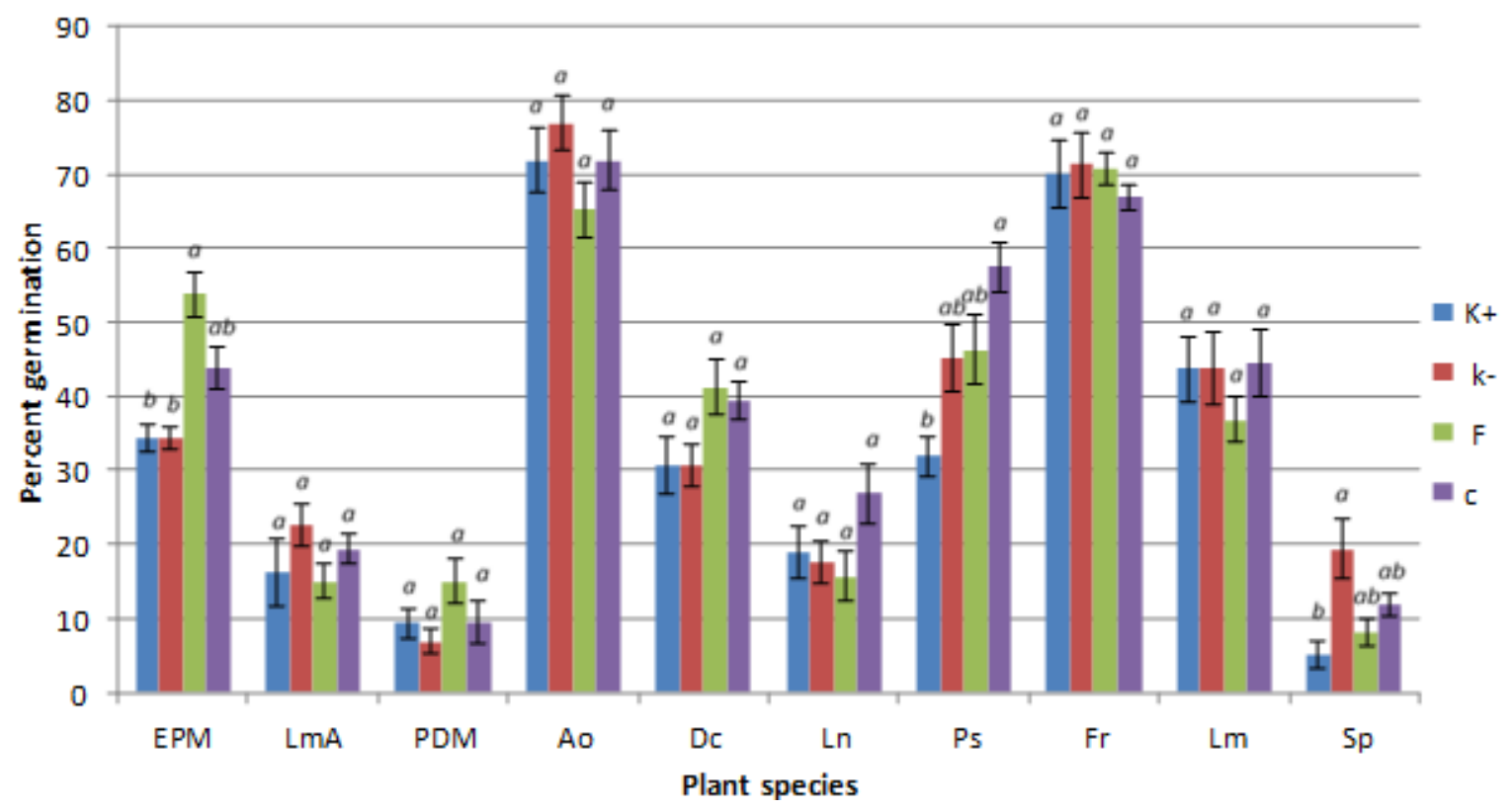

Figure 1 Mean percent germination over 30 days. Legend codes: 3.5 ml kelp extract per litre of water $(\mathrm{K}+)$, 1.5 ml per litre of water $(\mathrm{k}-), 2.5 \mathrm{ml}$ of slow release $10 \mathrm{~N}: 10 \mathrm{P}: 10 \mathrm{~K}$ fertilizer applied once $(\mathrm{F})$, no amendment control (C). Species codes: E. californica(EPM), L. maritima(LmA), P. grandiflora (PDM), A. odoratum (Ao), D. caespitosa (Dc), L. nivea (Ln), P. supina (Ps), F. rubra (Fr),L. multiflora (Lm), S. procumbens (Sp). Error bars represent standard error. Within a species, means that do not share a letter are significantly different.

The two species with the lowest mean seed weight(S.procumbens,P.grandiflora) had the lowest overall percent germination. The three species with the highest mean seed weight 
(A.odoratum, F.rubra, E.californica)had the highest overall percent germination.The highest percent germination was observed for A.odoratumin thek- treatment. The lowest percent germination was observed forS.procumbensin the $\mathrm{K}+$ treatment. It is possible that the large seeds may have shown higher germination than small seeds simply due to loss of small seeds below the surface due to the large spaces in the coarse growing medium. These results indicate thatseed size is important to consider when creating a seed mix for a green roof, since higher volumes of seed may be required for smaller seed in order for the species to compete with larger species.

\section{Biomass}

The weight were cumulative with all biomass, living and dead, from before and after the drought being combined. Six species (E.californica,L.maritima, A.odoratum, D. caespitosa,P. supina, and F.rubra) had significantly greater biomass in the F treatment compared toall other treatments. L.multiflorahad significantly greaterbiomass in the $\mathrm{F}$ treatment compared to the $\mathrm{K}+$ and $\mathrm{k}$ - treatments (Figure 2). For all but one species (L.nivea), greater biomass was observed in the fertilized treatment. ForL.niveathe control treatment had a slightly greater biomass then the F treatment. The treatment with the greatest biomass, L.maritima F treatment, was the first to die during the drought.Excluding $\mathrm{F}$ treatments, therewere five control treatments that produced greater biomass than the $\mathrm{K}+$ and $\mathrm{k}$ treatments

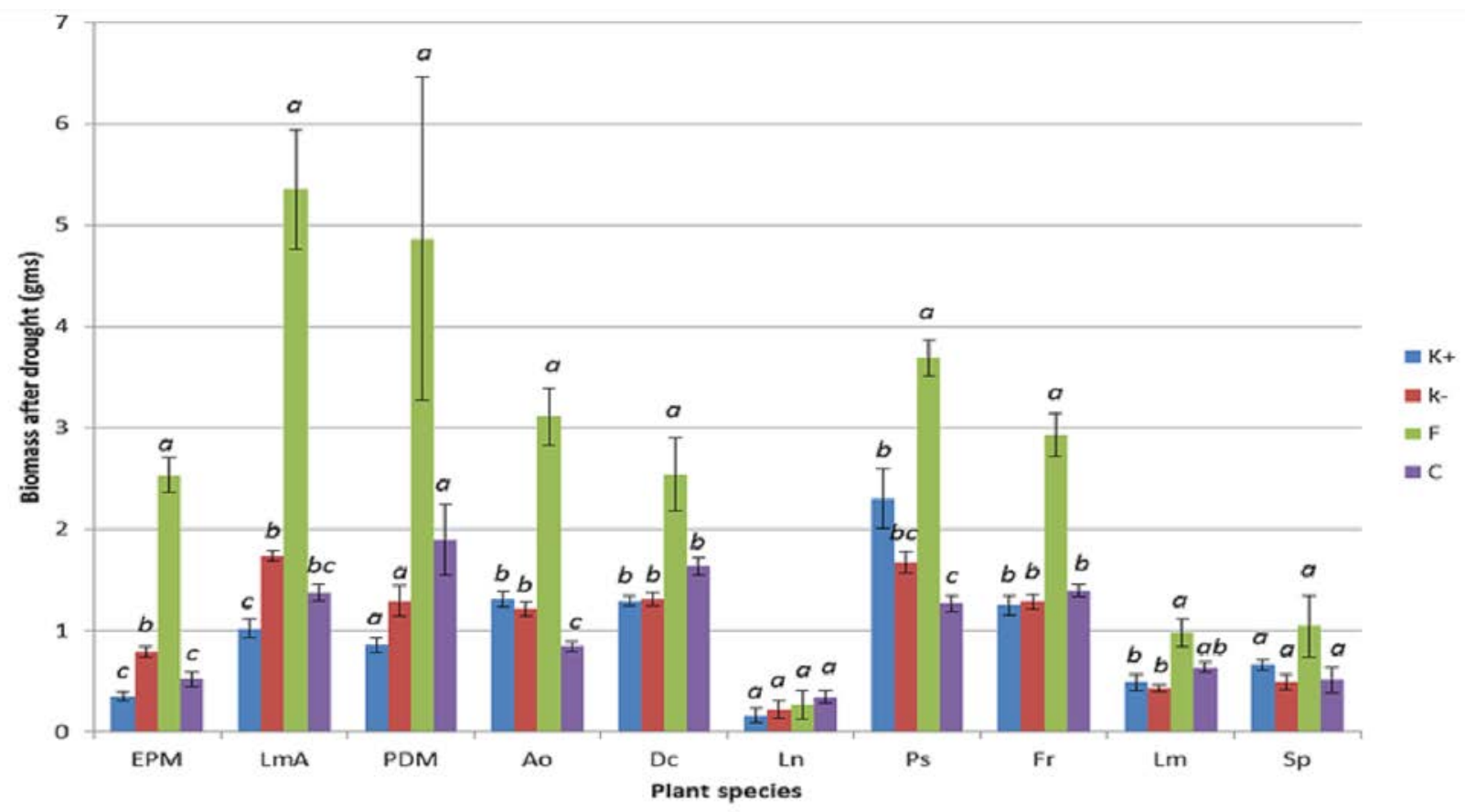

Figure 2 Mean biomass after two-month drought. Error bars represent standard error. Within a species, means that do not share a letter are significantly different. Legend codes: $3.5 \mathrm{ml}$ kelp extract per litre of water (K+), 1.5 $\mathrm{ml}$ per litre of water (k-), $2.5 \mathrm{ml}$ of slow release $10 \mathrm{~N}$ :10P:10K fertilizer applied once $(\mathrm{F})$, no amendment control (C). Species codes: E. californica(EPM), L. maritima(LmA), P. grandiflora (PDM), A. odoratum (Ao), D. caespitosa (Dc), L. nivea (Ln), P. supina (Ps), F. rubra (Fr),L. multiflora (Lm), S. procumbens (Sp). 
(P.grandiflora, D. caespitosa, L.nivea, F.rubra, L.multiflora), there were three $\mathrm{K}+$ treatments that produced greater biomass compared to the k- and C treatments (A.odoratum, P.supina, S.procumbens), and there were two k- treatments that produced greater biomass thanto the $\mathrm{K}+$ and $\mathrm{C}$ treatments (E.californica, L.maritima). Since the biomass of E.californicaandA.odoratumincreased in the kelp treatment(s) compared to the no amendment control, kelp may aid the growth of specific species.

\section{Volumetric water content (VWC)}

After a six-day drought on the green roof,significant differences between treatments were observed for five species(E.californica, P.supina, F.rubra, L.multiflora, A.odoratum).For these five species the $\mathrm{F}$ treatment had significantly lower VWCthanthe $\mathrm{K}+$ treatment. For E.californica, L.multiflora, andA.odoratum the $\mathrm{K}+$ treatment had significantly higher VWC than the $\mathrm{C}$ treatment. The lowest VWC was recorded for A.odoratum in the $\mathrm{F}$ treatment with a mean of $5.56 \%$. Additionally, the F treatment showed the lowest VWC for all species except $L$. maritimaand $L$. nivea.For the k- treatment the lowest VWC was observed forL.maritima, however the differences among the treatments for this species were less than 1\% (Figure 3). Differences in VWC were likely due to differences in biomass between treatments. However, significant differences in biomass were observed in treatments containing L.maritima,D.caespitosaandL.nivea even thoughthese treatments had equivalent VWC. Since the control was not significantly lower than the kelp treatments for these species this difference is likely due to specific plant traits.

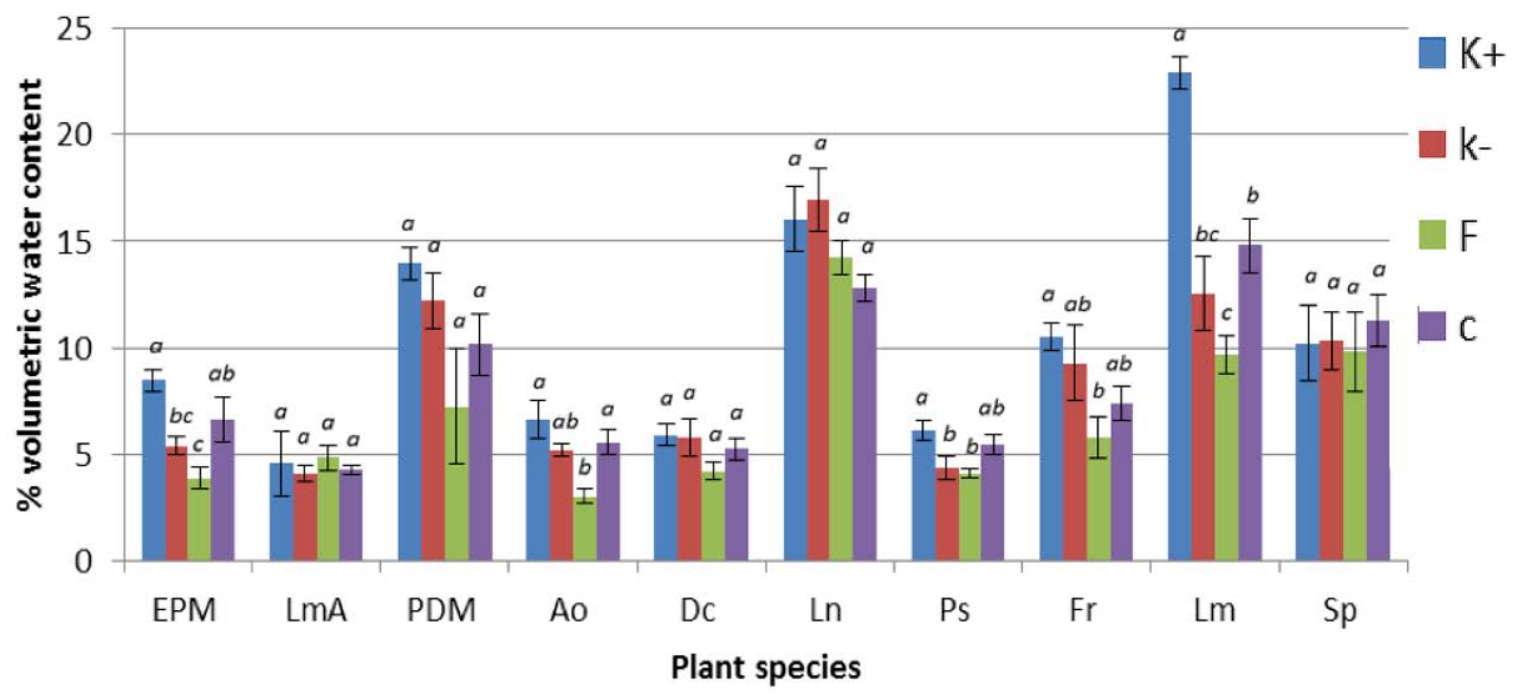

Figure 3 Percent mean volumetric water content on the sixth day of drought (July 17, 2013) on the Saint Mary's green roof. Error bars represent standard error. Within a species, means that do not share a letter are significantly different. Legend codes: $3.5 \mathrm{ml}$ kelp extract per litre of water $(\mathrm{K}+), 1.5 \mathrm{ml}$ per litre of water $(\mathrm{k}-)$, $2.5 \mathrm{ml}$ of slow release $10 \mathrm{~N}$ :10P:10K fertilizer applied once (F), no amendment control (C). Species codes: $E$. californica(EPM), L. maritima(LmA), P. grandiflora (PDM), A. odoratum (Ao), D. caespitosa (Dc), L. nivea (Ln), P. supina (Ps), F. rubra (Fr),L. multiflora (Lm), S. procumbens (Sp).

Although no significant differences were observed, resultssimilar to the six-day drought were observed for the two-month drought. For the two-month drought the F treatments had a lower VWC than all other treatments. On day seven of the two-month 
droughtVWC varied from a high of $29.38 \%$ (S.procumbens $\mathrm{K}+$ ) to a low of $11.2 \%$ (F.rubra F).On day 14, the highest VWC was 19.08\% (L.multiflora $\mathrm{K}+$ ) and the lowest was $3.68 \%$ (P.supinaF). When the average VWC for each treatment was combined the k- treatment had a slightly higher VWC than the $\mathrm{K}+$ treatment and the $\mathrm{F}$ treatment had the overall lowest VWC.On Day 14, the K+ treatments had the highest VWC and the F treatments had the lowest VWC.This trend continued on day 19.

\section{Health scores}

During the two-month drought the Ftreatments consistently decreased in health score days before all other treatments.The F treated E.californica,L.maritima, A.odoratumand F.rubra reached a health score of one significantly earlier thanthe $\mathrm{K}+$ and $\mathrm{k}$ - treatments. The L.niveaF treatment reached a health score of one significantly earlier then the ktreatment.Additionally, the F treated E.californica, L.maritima, A.odoratum,F.rubra and L.niveareached a health score of zero (dead) significantly earlier then the $\mathrm{K}+$ and $\mathrm{k}$ treatments(Table 2) (Figure 4). While health scores of 3-0 were recorded (as seen in Table 1), the most significant scores, in terms of poor health, are one and zero.

The majority of the trends observed for health score were likely do to differences in plant biomass. For example, the final biomass of E.californica, L.maritima, A.odoratum, and F.rubrain the F treatment were significantly greater than the biomass in all other treatments. This large biomass was likely a key factor in plant health deteriorating sooner, as larger plants tend to be less drought tolerant (Rowe et al., 2006).

However, biomass cannot be attributed to all the differences observed between treatments. For example, compared to the control treatment L.niveaandL.multiflorareached

Table 2Mean number of days until plants reached visual health scores of one and zero during the two-month drought. Health score: 1 (greater than $50 \%$ yellow or brown leaves, wilting, folded leaves), 0 (dead). Treatment codes: $3.5 \mathrm{ml}$ kelp extract per litre of water $(\mathrm{K}+), 1.5 \mathrm{ml}$ per litre of water $(\mathrm{k}-), 2.5 \mathrm{ml}$ of slow release 10N:10P:10K fertilizer applied once (F), no amendment control (C). Species codes: E. californica(EPM), $L$. maritima(LmA), P. grandiflora (PDM), A. odoratum (Ao), D. caespitosa (Dc), L. nivea (Ln), P. supina (Ps), F. rubra (Fr),L. multiflora (Lm), S. procumbens (Sp). Within a species, means that do not share a letter are significantly different. A “-” indicates the species never reached the indicated health score.

\begin{tabular}{|c|c|c|c|c|c|c|c|c|c|c|}
\hline & \multicolumn{10}{|c|}{ Health Score 1} \\
\hline & EPM & $\operatorname{LmA}$ & PDM & Ao & Dc & Ln & Ps & Er & $\mathbf{L m}$ & Sp \\
\hline $\mathrm{K}+$ & 20.6 a & $\begin{array}{l}15.25 \\
a\end{array}$ & $45.0 \mathrm{a}$ & $17.4 \mathrm{a}$ & 16.6 & $36.0 \mathrm{ab}$ & $12.0 \mathrm{a}$ & $23.0 \mathrm{a}$ & $34.2 \mathrm{a}$ & $23.5 \mathrm{a}$ \\
\hline k- & $18.4 \mathrm{a}$ & $14.2 \mathrm{a}$ & $36.3 \mathrm{a}$ & $14.6 \mathrm{~b}$ & $13.8 \mathrm{a}$ & $41.7 \mathrm{a}$ & $12.6 \mathrm{a}$ & $22.4 \mathrm{a}$ & $26.2 \mathrm{~b}$ & $20.8 \mathrm{a}$ \\
\hline $\mathrm{F}$ & $8.8 \mathrm{~b}$ & $7.8 \mathrm{~b}$ & $26.0 \mathrm{a}$ & $9.8 \mathrm{c}$ & $9.8 \mathrm{a}$ & $24.5 \mathrm{~b}$ & $10.4 \mathrm{a}$ & $13.8 \mathrm{~b}$ & $21.0 \mathrm{~b}$ & $18.2 \mathrm{a}$ \\
\hline $\mathrm{C}$ & $18.2 \mathrm{a}$ & $13.8 \mathrm{a}$ & $34.3 \mathrm{a}$ & $16.8 \mathrm{ab}$ & $13.8 \mathrm{a}$ & $26.6 \mathrm{~b}$ & $12.6 \mathrm{a}$ & $22.6 \mathrm{a}$ & $25.2 \mathrm{~b}$ & $22.4 \mathrm{a}$ \\
\hline \multicolumn{11}{|c|}{ Health Score 0} \\
\hline & EPM & LmA & PDM & Ao & Dc & Ln & Ps & Er & Lm & Sp \\
\hline $\mathrm{K}+$ & $28.0 \mathrm{a}$ & $19.0 \mathrm{a}$ & - & $19.6 \mathrm{a}$ & $18.8 \mathrm{a}$ & $40.5 \mathrm{ab}$ & $16.0 \mathrm{ab}$ & $28.0 \mathrm{a}$ & $41.4 \mathrm{a}$ & $26.0 \mathrm{a}$ \\
\hline k- & $25.0 \mathrm{a}$ & $16.8 \mathrm{a}$ & - & $18.0 \mathrm{~b}$ & $18.2 \mathrm{a}$ & $47.3 \mathrm{a}$ & $15.2 \mathrm{ab}$ & $30.4 \mathrm{a}$ & $33.8 \mathrm{~b}$ & $24.4 \mathrm{a}$ \\
\hline $\mathrm{F}$ & $14.4 \mathrm{~b}$ & $11.2 \mathrm{~b}$ & - & $13.0 \mathrm{c}$ & $14.0 \mathrm{a}$ & $27.0 \mathrm{~d}$ & $13.4 \mathrm{~b}$ & $16.2 \mathrm{~b}$ & $25.6 \mathrm{c}$ & $22.4 \mathrm{a}$ \\
\hline $\mathrm{C}$ & $25.6 \mathrm{a}$ & $16.8 \mathrm{a}$ & - & $19.2 \mathrm{ab}$ & $17.4 \mathrm{a}$ & $32.0 \mathrm{~b}$ & $17.4 \mathrm{a}$ & 25.6 a & $32.2 \mathrm{~b}$ & $25.6 \mathrm{a}$ \\
\hline
\end{tabular}


a health score of one and zero significantly later in the $\mathrm{k}$ - and $\mathrm{K}+$ treatments respectively, even though these treatments had equivalent biomass. This result indicates that kelp can have a positive effect on specific plant species. For L.maritimasignificantly smaller biomass was observed in the $\mathrm{C}$ treatmentcompared to the $\mathrm{k}$ - treatment and it took a comparable number of days for thesetreatments to reach a health score of one and zero.For L.nivea, no significantdifferences were observed between treatments for biomass, however the $\mathrm{F}$ treatment reached a health score of one significantly earlier thanthe k- treatment and zero significantly earlier thanall other treatments. More research is necessary to determine the specific characteristics that led to this result.

One species, P.grandiflora, survived the entire two-month drought.This plant is a C4 dicot that can also exhibit CAM photosynthesis (Guralnick et al., 2002; Ku et al., 1981). P.grandiflora continued to flower 58 days into the drought and showed viable flower buds at the end of the experiment. To provide a reference point for this species,the other two species with the latest flowering times were E.californica for which flowering ended 9 days into the drought, and L.maritimafor whichflowering ended 16 days into the drought. All three annual species in all treatments were able to set seed. This indicates that these species could be viable in the green roof environment.

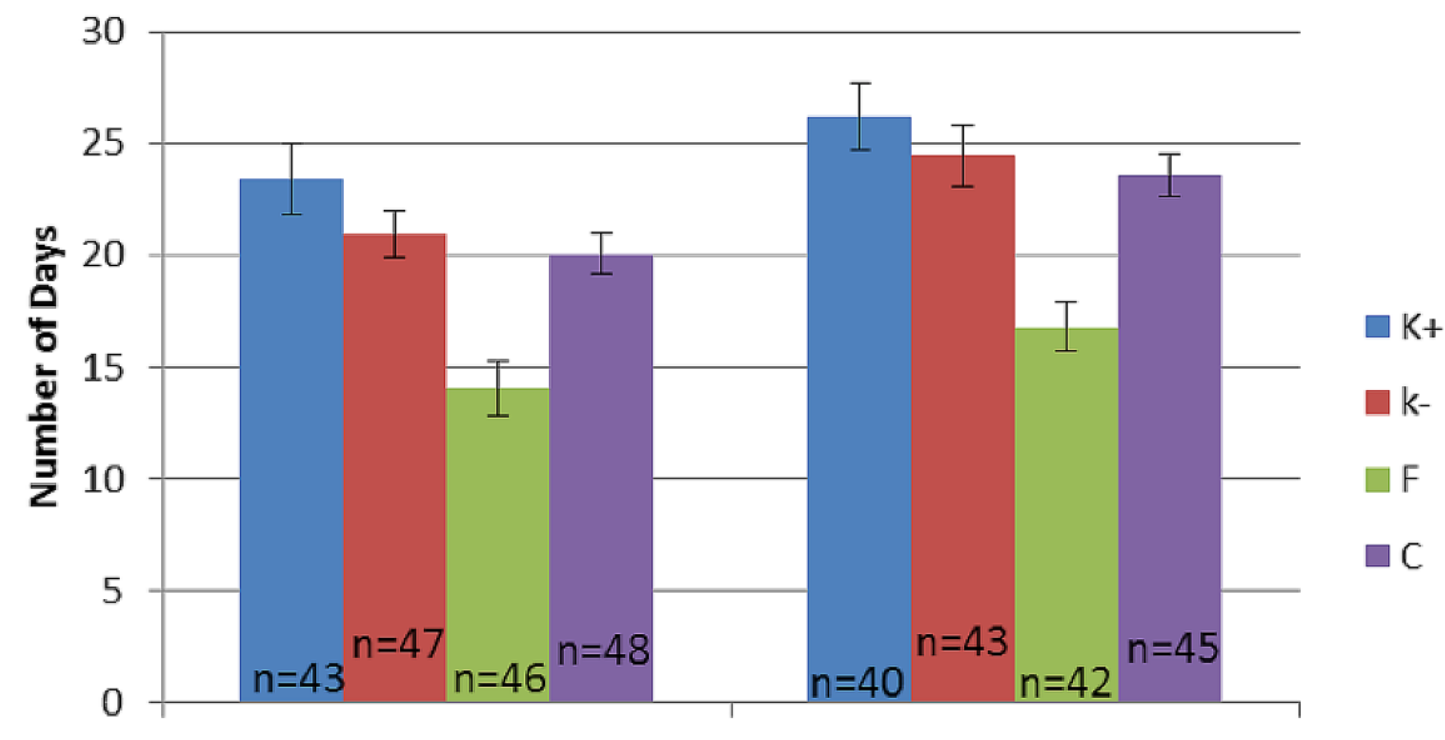

One $n=45$

Health Score

Figure 4Mean number of days it took all plant species to reach health scores of one and zero during the two-month drought. Health score: 1 (greater than 50\% yellow or brown leaves, wilting, folded leaves), 0 (dead). Treatment codes: $3.5 \mathrm{ml}$ kelp extract per litre of water $(\mathrm{K}+), 1.5 \mathrm{ml}$ per litre of water (k-), $2.5 \mathrm{ml}$ of slow release 10N:10P:10K fertilizer applied once (F), no amendment control (C).

\section{CONCLUSIONS}

Seeding a green roof can economically produce healthy green roof plants (Nagase \&Dunnett 2013; Sutton, 2013).In this experiment, smaller seeds had lower germination rates while larger seeds had higher germination.Using larger volumes of smaller seed is recommended in order for these plants to compete with the larger seeded species. 
Plant size can affect green roof performance, larger plants can provide more cover on a green roof, absorb more stormwater and capture more particulate pollution. These benefits are useful, but not if the plants are dead.The larger biomass produced by the fertilizer treatments in this study made the plants vulnerable to drought conditions.In a stressful green roof setting, where high winds, shallow substrate, and high irradiance can quickly dry out the soil, large plants can be a disadvantage.

In this experiment, fertilizer was beneficial for germination and early biomass production.It was not beneficial in drought conditions for long-term survival and created plant health problems even in a six-day drought.This was partly due to the higher biomass production making the fertilized plants vulnerable to a longer drought later in the season.The plants in the k- treatment showed healthy plant growth that was resilient than the F treatment in drought conditions. While the possibility of a two-week drought is realistic on green roofs in most climates, many k-treated plants were healthy for over two weeks with no water.

Kelp extract significantly improved the drought tolerance of two of the plant species tested.This result indicates that kelp could be a useful green roof amendment that can improve substrate water retention, plant growth, and plant health on a green roof. Continued research should include ways to determine which plant species may benefit from kelp, and what the optimal volume and frequency of kelp application is for specific species.Combining kelp with fertilizer might create a synergistic effect creating larger, healthy plants more resistant to drought than plants just treated with one of the amendments.

Choosing a diverse mixture of plant species may offer a green roof some protection from plant loss during a drought as some species in the experiment died quicker than others.Annuals provide seed for future survival of the population and may be more economical to establish than green roofs planted with perennials (Nagase \&Dunnett 2013).Their quick life cycle was beneficial as all annual species set seed in the experiment.Perennials may die in a drought, while seed could persist and germinate when moisture returned.Annuals in this experiment all produced seed and the seeds of L.maritima and S.procumbensgerminated in July showing the possibility of another life cycle before the end of the season. This was a short-term experiment (four months) compared to the possible time a green roof might exist as urban green infrastructure.Long-term performance could show different results and plant communities would evolve overtime and may be quite different compared to this brief period of time. For example a 7-year study by Rowe et al. (2012) found that of the 22 species present after the first growing season only seven remained by the end of the fifth growing season.If green roofs are to be sustainable, they will have to be resilient to environmental stresses such as drought.A bio-diverse green roof containing annuals, cultivated grasses, and native plants could be considered a long-term, novel urban ecosystem (Seabrook et al. 2011) and could contribute to urban green space by offering a variety of benefits that come from a green roof system.

\section{ACKNOWLEDGEMENTS}

We thank Joy Schmidt and Vitaroofs for funding the project and providing technical advice on green roof systems. NSERC also contributed funding via a Collaborative Research and Development grant to JL. 


\section{LITERATURECITED}

Butler, C., C. Orians, 2011. "Sedum cools soil and can improve neighboring plant performance during water deficit on a green roof.”Ecological Engineeringno. 37:1796-1803.

Crouch, I., J. van Staden, 1993. "Evidence for the presence of plant growth regulators in commercial seaweed products.”Plant Growth Regulationno. 13:21-29.

Berndtsson, J.,2010. "Green roof performance towards management of runoff water quantity and quality: a review.”Ecological Engineering 3:351-360.

Dvorak, B., A. Volder, 2010. “Green roof vegetation for North American ecoregions: a literature review.”Landscape and Urban Planningno. 96:197-213.

Emilsson, T., Berndtsson, J. Mattsson, K. Rolf, 2007. 'Effect of using conventional and controlled release fertiliser on nutrient runoff from various vegetated roof systems."Ecological Engineeringno. 29:260-271.

Fernandez-Canero, R., T. Emilsson, C. Fernandex-Barba, M.Machuca, 2013.“Green roof systems: A study of public attitudes and preferences in southern Spain.”Journal ofEnvironmental Managementno. 128:106-115.

Guralnick, L., G. Edwards, M. Ku, B. Hockema, V. Franceschi, 2002."Photosynthetic and anatomical characteristics in the $\mathrm{C}_{4}$-crassulacean acid metabolism-cycling plant Portulacagrandiflora.” Functional Plant Biology 29(6):763-773.

Haslam, S.,D.Hopkin., 1996. "Physical and biological effects of kelp (seaweed) added to soil.”Applied Soil Ecologyno. 3:257-261.

Khan, W., U. Rayirath, S. Subramanian, M. Jithe, P. Rayorath, D. Hodges, A. Critchley, J. Craigie, J. Norrie, J.Prithiviraj, 2009."Seaweed extracts as biostimulants of plant growth and development.”Journal of Plant Growth Regulationno. 28:386-399.

Kircher, W., 2004.“Annuals and Sedum-cuttings in seed-mixtures for extensive roof gardens.”Proceeding JC on Urban Horticulture.ActaHort 643, ISHS.

Köhler, M., P. Poll, 2010.“Long-term performance of selected old Berlin greenroofs in comparison to younger extensive greenroofs in Berlin.”Ecological Engineeringno. 36:722-729.

Ku, M., Y. Shieh, B. Rege, C. Black, 1981."Photosynthetic characteristics of Portulacagrandiflora, a succulent C(4) dicot: cellular compartmentation of enzymes and acid metabolism."Plant Physiology 68(5):1073-80.

Lundholm, J., J. MacIvor, Z. MacKougall, M. Ranalli, 2010.“Plant species and functional group combinations affect green roof ecosystem functions.”PLOS ONE 5(3):1-11.

McDonough, W.,M. Braungart, 2002.Cradle to cradle: Remaking the way we make things.North Point Press, New York. USA. 
Monterusso, M., B. Rowe, C. Rugh, 2005."Establishment and persistence of Sedum spp. and native taxa for green roof applications.”HortScience 40(2): 391-396.

Nagase, A., N. Dunnett, 2010. "Drought tolerance in different vegetation types for extensive green roofs: Effects of watering and diversity.”Landscape and Urban Planningno. 97:318-327.

Nagase, A., N. Dunnett, 2013. "Establishment of an annual meadow on extensive green roofs in the UK.”Landscape and Urban Planningno. 112:50-62.

Oberndorfer, E., J. Lundholm, B. Bass, B.,R.Coffman, H. Doshi, N. Dunnett, S. Gaffin, M. Kohler, K. Liu, B. Rowe, 2007. "Green roofs as urban ecosystems:ecological structures, functions, and services.”BioScienceno. 57:823-833.

Ohsowski, B., J.Klironomos, K. Dunfield, M. Hart, 2012.“The potential of soil amendments for restoring severely disturbed grasslands.”Applied Soil Ecologyno. 60:77-83.

Papenfus, H., M. Kulkarni, W, Stir, J. Finnie, J. Van Staden, 2013. “Effect of a commercial seaweed extract (Kelpak) and polyamines on nutrient-deprived (N, P and K) okra seedlings.”ScientiaHorticulturaeno. 151:142-146.

Rowe, B., 2011. “Green roofs as a means of pollution abatement.”Environmental Pollutionno. 159: 2100-2110.

Rowe, B., K. Getter,A. Durhman, 2012. "Effect of green roof media depth on Crassulacean plant succession over seven years.”Landscape and Urban Planning 104(34): 310-319.

Rowe, B, M. Monterusso, C. Rugh, 2006. "Assessment of heat-expanded slate and fertility requirements in green roof substrates.”HortTechnology 16(3): 471-477.

Rayorath, P., M. Jithesh, A. Farid, W. Khan, R. Palanisamy, S. Hankins, A. Critchley, B. Prithiviraj, 2008. "Rapid bioassays to evaluate the plant growth promoting activity of Ascophyllumnodosum(L.) Le Jol. Using a model plant, Arabidopisis thaliana (L.) Heynh.” Journal of Applied Phycologyno. 20:423-429.

Saadatian, O., K. Sopian, C. Lim, S. Riffat, E. Saadatian, A. Toudeshki, M. Sulaiman, 2013.“A review of energy aspects of green roofs.”Renewable and Sustainable Energy Reviews no. 23:155-168.

Seabrook, L., C. Mcalpine, M. Bowen, 2011.“Restore, repair or reinvent:Options for sustainable landscapes in a changing climate.”Landscape and Urban Planningno. 100:407-410.

Spann, T.M.H. Little, 2011.Applications of a commercial extract of the brown seaweed Ascophyllumnodosumincreases drought tolerance in container-grown 'Hamlin' sweet orange nursery trees.HortScience 46(4):577-582.

Sutton, R., 2013. “Seeding green roofs with native grasses.” Journal of Living Architecture.November 1(1):15-35. 
Thorsen, M.,S.Woodward, B. McKenzie, 2010.“Kelp (Laminariadigitata) increases germination and affects rooting and plant vigour in crops and native plants from an arable grassland in the Outer Hebrides, Scotland.”Journal of Coastal Conservationno. 14:239-247.

Ugarte, R., G. Sharp, 2012.“Management and production of the brown algae Ascophyllumnodosumin the Canadian maritimes.”Journal of Applied Phycologyno. 24:409-416.

Yuen, B., W. Hien, 2005.“Resident perceptions and expectations of rooftop gardens in Singapore.”Landscape and Urban Planning 73:263-276. 